\title{
Cessation of non-marital cohabitation and shared custody of pets
}

\author{
Margherita Pittalis
}

Associate Professor of Private Law and Sports Law, University of Bologna, Italy

Attorney in Bologna, Italy

Recommended citation. PITTALIS, M., Cessation of non-marital cohabitation and shared custody of pets, dA. Derecho Animal (Forum of Animal Law Studies) 10/1 (2019)

DOI https://doi.org/10.5565/rev/da.412

\section{Primary publication}

This case note was published in Italian, in Famiglia e Diritto, 5 (2017) 460-476.

Disclaimer: The translations contained in this commentary are unofficial and provided for information only.

\begin{abstract}
In a judgment, the Court of First Instance in Rome establishes shared custody of the family pet in in the aftermath of an extra-marital cohabitation cessation and consequent partners' disagreement on the issue. The Court indicates rules of conduct for pet custody and maintenance. Court's decision grounds on the analogical application of the norms about custody of children and on the evaluation of the material, spiritual ad affective interest of the pet. The author highlights the remarkable court's attempt in overcoming the traditional concept of pets conceived as res and, starting from this decision, indicates which perspectives the law can follow in this respect.
\end{abstract}

Keywords: extra-marital cohabitation; disagreement; pet custody; children.

Resumen - Cese de la cohabitación no marital y custodia compartida de animales de compañia

En una sentencia, el Tribunal de Primera Instancia de Roma establece la custodia compartida de la mascota de la familia tras un cese de cohabitación no marital y el consiguiente desacuerdo de las partes sobre el tema. El Tribunal indica normas de conducta para la custodia y el mantenimiento de la mascota. La decisión del Tribunal se basa en la aplicación analógica de las normas sobre la custodia de los niños y en la evaluación del interés material, espiritual y afectivo del animal de compañía. El autor destaca el notable intento del Tribunal por superar el concepto tradicional de mascotas concebidas como res y, a partir de esta decisión, indica qué perspectivas puede seguir la ley en este sentido.

Palabras clave: cohabitación no marital; desacuerdo; custodia de la mascota; niños. 


\section{Animal Custody}

\section{Court of Rome, $5^{\text {th }}$ section, March 12-15 2016, n. 5322 (Unofficial translation)}

The enactment of a draft law, submitted for a long time in the Italian Parliament, is desirable. The draft law aims at introducing in the Italian civil code a new article, namely, Art. 455 ter called "Custody of family's animals in case of spouses' separation" and it states as follows: "In case of spouses' separation and in the absence of any agreement between parts, the Court gives either the shared or the exclusive custody to the part who can provide the greatest level of wellness to the pet. The Court decided regardless of any communal or separated estate settlement and regardless of any information provided by the registry office about the pet. Hearings with spouses, cohabitants, their progeny and, possibly, specialist in animals' behaviours are set before the final decision. The Court is competent for deciding upon the custody of a pet even in case of cessation of non-marital cohabitation." In the given case, particularly, the Court argues on which part can better provide for the material-spiritual-affective interest of the pet, balancing this interest with the affective one each part have toward the pet. Considering all factors, the Court comes to set a shared custody with equal division among parts of costs for the maintenance of the pet (food, healthcare, etc.). For the Court the shared custody is the best option regardless the fact that the parts were non-marital cohabitants. Concerned draft law, in fact, gives the Courts competence for deciding upon pet custody even in cases of cessation of non-marital cohabitation. In addition to it, the jurisprudence is more and more willing to compare de facto family on the one hand and family founded on marriage on the other. What stands out is that, from the dog's point of view, the difference between marital or non-marital cohabitation is completely irrelevant: the dog is tied up to both parts, emotionally speaking, regardless of their legal relationship. After all, the dog is not even able to perceive the legal difference. The same happens with children: even though they are able to discern between marriage and de facto family, it does not affect the feelings they have for their parents. In the given case, the defendant did not allow the claimant to see their dog. This obstacle was so negatively affecting her that she went before a Court to assess her right to have custody of the dog, asking in addition for a compensation for damages caused by the behaviour of the defendant.

\begin{tabular}{|l|l|}
\hline \multicolumn{2}{|c|}{ Case-law guidelines } \\
\hline Compliant & $\begin{array}{l}\text { Court of Pescara, May 9, 2002; Court of Cremona, June 11, 2008; Court of Milan, } \\
\text { March 13, 2013. }\end{array}$ \\
\hline Non-compliant & Court of Milan, March 2, 2011; Court of Como, February 3, 2016 \\
\hline
\end{tabular}

\section{The Court}

\section{Omissis}

A writ of summons is produced for consideration of the Court where the claimant asks the Court for the defendant to be joined in the proceeding. As for facts, the claimant adopted a dog called ..., registered at relating registry office with regular microchip. The claimant picked the dog up from the street and took care of him in her house while she was in a relationship with the defendant. After the two parts split, the cohabitation ceased and the claimant carried the dog with her in her new house. After the separation, the defendant kept seeing the dog under claimant's permission for a certain amount of hours a day. On December 16, 2011, the claimant agreed to let the defendant keep the dog with him, during weekends, in his country house. Since that moment, however, the defendant has never given the dog back to the claimant, even preventing her seeing the pet. For this reason, the claimant went before the Court asking for the restitution of the dog illicitly detained by the defendant and for compensation for damages caused by the deprivation of her dog whose proposed amount corresponds to $€ 15.000$. The Court is nonetheless entitled to calculate a different amount. The defendant appeared promptly before the Court. He answered to accusations stating that the dog has been found in 2006 nearby his own house and that he had always taken care of the pet during the cohabitation with the claimant, providing healthcare assistance. He then explained that the microchip was linked to the claimant name just because only the claimant fulfilled the residence 
prerequisite in order to be called as dog responsible. The defendant added that, at any rate, to be called as responsible in the registry office does not imply to be exclusive owner of a pet, especially when a family or a cohabitation is at stake. Subsequently, the defendant rejected what declared by the claimant, insofar as, after the separation, in defendant's opinion, the dog has always lived in his house. Again, the defendant pointed out that recent legislative and jurisprudential evolutions tend to assess the principle of the wellness of the animal as the main and ultimate criterion to take into account when it comes to decide upon the custody of a pet after the cessation of a marriage or cohabitation. The defendant finally asks the Court for the rejection of claimant's requests. He further asked to be recognized as the formal and factual owner of the dog. He finally asked for compensation for damages for an amount of $€ 15.000$. Even in this case, the Court could provide for a different amount. During investigation, both claimant and defendant have been heard and written documents have been provided. On trial dated May 25, 2015, parts concluded as reported. The Court came up with decision on that same day.

National legislation lacks of a provision about pet custody in case of spouses' separations. As it often happens, the Legislator runs late compared with social changes (for instance, the legal role of the legitimate son and of the natural son had been compared only in 2012 while same-sex marriage are still in the middle of a vivid political battle). Courts are more and more asked to decide upon pet custody after parts' separations. Considered the legislative shortcoming, judges are forced in creating a legal principle to discuss these cases. Two are the main decision in this respect: in the first one, held by the Court of Foggia, the judge addressed pet custody to one part and daily visiting rights to the other; in the second decision, held by the Court of Cremona, both parts obtained pet custody with an equal division of costs for pet maintenance. Both Courts, in the absence of a norm as reference, applied by analogy norms about children custody. Regardless the fact judges decided differently, in both cases it was the material-spiritual-affective principle to guide them. The court here at stake argues in favour of the case law that, after all, simply anticipates what a draft law, submitted in the Italian Parliament for a long time, states, aiming at introducing art.455 ter in the Italian civil code. This article states as follows: "In case of spouses' separation and in the absence of any agreement between parts, the Court gives either the shared or the exclusive custody to the part who can provide the greatest level of wellness to the pet. The Court decided regardless of any communal or separated estate settlement and regardless of any information provided by the registry office about the pet. Hearings with spouses, cohabitants, their progeny and, possibly, specialist in animals' behaviours are set before the final decision. The Court is competent for deciding upon the custody of a pet even in case of cessation of non-marital cohabitation". In the case at stake, the Court establishes that the legal regime, who can better provide for the material-spiritual and affective interest of the pet, principle nonetheless balanced with the parts' interests too, is the shared custody with equal division of costs for pet maintenance (food, healthcare, etc.). What emerges from investigations is, in fact, that the dog has lived with the parts for three years during their relationship and that, after the separation, the pet kept living with both parts alternatively until 2012. Moreover, the court states, from the dog's point of view, it is irrelevant which one of the parts has first detained the pet after the separation since both parts took care, before and after the separation, of the dog (as documents demonstrate). It is clear therefore that the dog get attached to both parts, identifying both of them as its "owners" and that he certainly get accustomed, all along three years, to different houses and lifestyles. Furthermore, the fact that the dog has not been seeing the claimant for three years is irrelevant according to the fact that, thanks to their strong emotional memory, dogs are able to remember people they were linked to, despite long-lasting absences: in the case at stake, three years of absence cannot delete six years of mutual affection. Furthermore, it is argued that shared custody can be addressed even in case of ceased non-marital cohabitation and not only in case of ceased marriage as cases, recalled before, states. In fact, the draft law at stake addresses to court the competence to decide upon pet custody even in case of cessation of non-marital cohabitation. The case law too increasingly tends to compare de facto family and family grounded on marriage. At any rate, what really stands out is that, considering the point of view which ultimately has importance, that is that of the pet, it is totally irrelevant whether the parts are married or not: pet's affection for its owners does not rely on the legal regime existing between parts. Pets are not even able to discern the difference between different regimes. Likewise, children do not pay attention on their parents' legal regime, even though (and unlike pets) they are fully aware of the differences. The Court at issue claims both judicial request not to be fully acceptable and states that the defendant is in charge of all proceeding costs, considering that thanks to its behaving he grabbed the claimant from a strong affection, preventing her from seeing the pet for long time. It was this deprivation, in fact, that forced the claimant to go before the Court.

For these reasons, 
The Ordinary Court decided for the shared custody of the pet and that both parts have to take care conjunctively of the dog. Each part has to provide for $50 \%$ of costs for the maintenance of the dog (that is, food, healthcare assistance and everything needed for its wellness). The Court states that each part has to keep the dog for six months a year. While one part has the pet in custody for his/her legitimate period, the other part has visiting rights and can have it in custody two days a week, nights included. The Court addresses the pet custody to the claimant for six months after the publication of the decision. Finally, the defendant is condemned in paying for proceeding costs, included costs for legal defence.

\section{Omiss}

\section{Cessation of non-marital cohabitation and shared custody of pets}

\section{The case}

The concerned case constitutes a unique decision in its own kind. None case before indicates a shared custody as solution following, on the one hand, a disagreement between partners and, on the other, the cessation of a non-marital cohabitation as the current one does. Precedent jurisprudence is in fact about cases of consensual legal separation of spouses. Only one decision concerned a separation of spouses who disagreed of the two on the pet custody; in that case, however, only to one of the two spouses obtained the custody of the pet, while the other obtained only visiting rights.

The current decision represents therefore a precedent regarding cessation of non-marital cohabitation and shared custody of the pet.

A decision of February 3, 2016 by the Court of First Instance of Como approved a spouses' consensual separation agreement regulating the shared custody of a pet with consensual division of costs for the pet's maintaining and caring ${ }^{1}$. Soon after, the decision at stake in this work occurred. More precisely, the judgment establishes that the custody of the pet is given to both ex-spouses with a division of costs amounting to $50 \%$ each one. The case was introduced before the court by the spouse the registry office claimed to be the pet responsible. She specifically asked for the restitution of the pet at stake by the other spouse detaining at that tome the animal and for compensation of damages caused by the deprivation of the pet. As for facts, in the claimant's words, the pet at stake was a stray dog, living in the streets. The claimant herself adopted the dog and registered it identifying herself as responsible for the pet. The adoption occurred while she was in a relationship with the defendant. When they ceased the relationship and cohabitation, the claimant kept taking care of the pet in her new home, while the defendant could only visit the dog daily according to his ex-spouse permission. This agreement went on regularly until the claimant, subsequently, allowed her ex-spouse to keep the pet in his country house during a weekend under condition of giving the pet back in the aftermath. At that point, however, the defendant did not return the pet to the claimant, even preventing her to see the dog.

The claimant introduced a wit of summons before the court in order to obtain the restitution of the dog improperly detained and a compensation of damages of $€ 15.000,00$ due to the unlawfully deprivation of the dog, leaving open the option for the judge to redefine the amount on an equitable basis or considering the judicial needs.

Hence, the defendant appeared before the court carrying out several objections. In particular that: -the dog was found next to his house; -during the cohabitation he himself took care of the pet, ensuring for the pet the required healthcare assistance;-his spouse was identified as responsible for the pet in the registry office only because she was the only between the two to be registered as resident in Rome; - at any rate, the identification via microchip does not imply by necessity the right of property over the dog to the one who is responsible. The defendant then added that, conversely to what the claimant stated, after the couple split, the dog remained in defendant's custody.

The defendant concluded that, considering recent jurisprudence, the only principle of the pet's

\footnotetext{
${ }^{1}$ The ex-spouses decided specifically that: -the dog was of both pats property regardless the fact the registry office entitled the husband only as dog responsible. Therefore, decisions on the dog should be taken by agreement of both parts; -the dog should have lived all its life in the wife's house, except for other part's visiting rights as established in the agreement;-the husband should have given a monthly amount of $€ 250,00$ for the dog maintenance for contributing to dog-sitting costs. The amount has to be paid in the fifth day of each month and has to be reassessed according to the ISTAT indicators (for family and workers) ruling from January 1 , 2017; the husband has, furthermore, to provide dry food for the dog". Healthcare costs are provided by both parts ( $80 \%$ of costs are financed by the husband and $20 \%$ by the wife); -During the weekend, the dog is cared alternatively by each part from Friday at $6 \mathrm{pm}$ to Sunday at 8pm"; moreover during the week, ex partners can set further meetings according to their work schedule"; subsequently, "parts have to concur with each other the any type of vacation they will respectively spend with their pet."
} 
wellness is the only principle to be taken into account in order to establish which one of the ex-spouses must take custody of a pet. Hence, the defendant required the rejection of the claimant demand and counter claimed for the recognition of his factual and legal right to custody of the pet to be recognized. In addition to it, the defendant asked for a compensation for damages considering the costs incurred until that moment for the pet maintenance the amount of which corresponds either to $€ 15.000$ according to his own calculations or to the different amount proposed by the court. Investigations revealed that the dog lived with the couple for three years in the same apartment and after the two stopped living together following the separation, the pet custody and assistance was carried out alternatively by both ex-spouses in different houses. The dog was therefore devoted to both parts, identifying both as its "caregivers". For the three years, after the separation, the pet lived once in the house of one part once in the other part's house and get accustomed to different lifestyles. Based on all those elements, the Court did not take into account the fact that the dog was kept away from the claimant for three years. In fact, it is well-know that dogs have a strong emotional memory therefore the concerned dog could not possible have forgotten six years of the claimant's caregiving as these were the amount of time the claimant spent with the pet. That stating, the Court decided for the shared custody of the dog with equal allocation of costs for dog's maintenance and assistance (namely, healthcare, food and everything is needed for the pet's wellness) corresponding of 50\% of total amount for each part.

More precisely, the shared custody was regulated as follow: each part is entitled to keep and take care of the dog in his/her own house for six months a year and to visit or host it twice a week (continuously or not) during the lasting six months. The judgment then established that in the first six months following the publication of the sentence, the claimant is entitled to keep the dog.

\section{Reasoning of the Court}

This decision implicitly considers the request for a pet's custody made by ex-non-marital cohabitants who did not reach an agreement in this respect eligible. The Court has therefore considered the merits of the case at stake. ${ }^{2}$

The court first pointed out that a legislative provision in this respect is still inexistent. However, more and more courts are required to decide on pet's custody when a couple of spouses take charge of a pet during cohabitation and split subsequently. Courts therefore come up with judicial precedents in this respect in order to fill the legislative gap. In this judgment, the Court has recalled relevant cases as Courts of Foggia $^{3}$ and Cremona ${ }^{4}$ decisions. The former has given to one part the custody of the pet and to the other only a daily visiting right; the latter approved an agreement, consensually carried out by parties, establishing the shared custody of the pet with equal allocation of costs for the pet's maintenance.

In this respect, the Court of Rome observed that, in the absence of a norm, the above-mentioned courts applied by analogy norms concerning children custody. It has remarked that the" interest over which those courts had grounded their decision (...) was ultimately the "material-spiritual-affective pet's interest". 5

That premised, the given Court has decided to follow this case law considering that "it does not nothing but anticipate the enactment of a legislative proposal mooted for many years aiming at introducing a new article, namely, art. 455 ter (pet custody in case of separation of spouses), in the civil code". The judgment at stake partially reproduces the content of the legislative proposal precisely when it establishes the exclusive or shared custody of the pet to the ex-spouse who can ensure the greater level of wellness to the pet itself.

In applying those principles, the Court of Rome considered that in the given case "the legal regime better providing for the material-spiritual-affective interest of the pet, in conjunction with the affective

\footnotetext{
${ }^{2}$ On the contrary, the Court of Milan (March 2, 2011), in a case of spouses' judicial separation, claimed the issue on the custody of the pet to be inadmissible simply according to the fact that a legislative provision was missing in this respect. It therefore did not decide on the merits the issue at stake. Moreover, the Court of Como (February 3, 2016) agreed in this respect with the Court of Milan stating that, in case of spouses' disagreement, the judge has not the duty to decide on the pet custody and that this issues are willing to be set privately by parts through agreement or, in any case, via extra-judicial means. On this topic, the author provides a strong criticism: in particular, whenever the spouses agree on each issue except for the pet custody, this latter has to be set judicially since it is still part of the judicial separation, therefore, part of the issues the judge is competent to decide upon.

${ }^{3}$ Unprecedented decision. References on http://www.laleggepertutti.it/2778in-caso-di-separazione-a-chi-viene-affidato-lanimaledomestico

4 Unprecedented decision, again. http://www.quotidianogiuridico.it/documents/2016/03/30/separazione-consensuale-visita-emantenimento-del-cane-rientrano-nell'-accordo

${ }_{5}^{5}$ Arguing this way, it is proper in the author's opinion to underline that the Court of Foggia decided the pet custody to be given to the part who can better afford the best development possible of the pet identity; likewise, the Court of Pescara (May 9, 2002). Still, the Court of Milan (March 13, 2003) who has pointed out the animal to be a "sentient living being" according to the Treaty of Lisbon which set the dignity of the animal as a principle.
} 
interest of both parts concerned, is the shared custody with equal division of costs for the pet's maintenance (food, healthcare etc..)". Determining for the decision was the parts' behaving which, soon after the split, adopted the same solution proposed by the Court later.

The Court deemed the shared custody of the pet to be applicable whenever the parts are married or not. The above-mentioned legislative proposal, in fact, states that the Court's competence encompasses decisions on the custody of a pet even in cases of cessation of non-marital cohabitations in line with the case law that tends more and more to equate de facto family and that grounded on a marital status. Conversely, previous case law, the Court itself recalled in the case at issue, affirmed that pet parts obtain pet custody only on the base of legal cessation of marital cohabitations. In this respect, the Court added that "from the dog's point of view, which is the factor who ultimately counts, it is irrelevant whether their 'owners' are married or not: the affection the pet feels for both owners ignores the legal regime of the couple" that the dog, moreover, is not able to perceive. The Court compared this kind of irrelevance to the one "children feel, even if" and contrary to pets, "children can fully understand the difference between the two regimes".

Arguing this way, the Court rejected both the claimant's demands, namely, the restitution of the pet and the compensatory one (even because it was ungrounded) and the defendant's counter-claim, that is, the recognition of his factual and legal entitlement in detaining the dog and the compensation for damages he asked for. The court addressed to the defendant the payment of all costs stating that the claimant was forced to go before the Court because the defendant had prevented the claimant from seeing the pet in the later years.

The Court therefore decided for the shared custody of the pet between the two parts with equal division of the costs for the pet's maintenance (that is "healthcare, food and everything possibly necessary for the wellness of the pet"), without taking into account the fact that the microchip identified the claimant as responsible for the pet.

As highlighted, the judge grounded his decision on the supposed analogic applicability of norms concerning children custody, without mentioning the important results achieved mostly at international level on animal's and, in particular, pets' rights.

\section{The animal - from res to entitled of rights}

The notion of "pet" is conceived in two ways: traditionally, pets are conceived of res while in recent times, both international and national legislative provisions tend increasingly to classify pets as "sentient living beings" or, sometimes as "not human individual". 6

Relying on the former or the latter interpretation is determinant when it comes to discuss the custody

\footnotetext{
${ }^{6}$ Several decisions recognizing the subjectivity of animals and their rights from all over the world are at stake. Pivotal is the decision by the Court of Buenos Aires. In this 2014 decision, the Court has qualified a 29 years old female orangutan, called Sandra, as "nonhuman individual" worthy of full liberty. This way, the Court established that the orangutan should move from the zoo she lived in to a nature reserve, hosting animals saved from ill-treatments. Orangutan rights have been pursued by Lawyers Association for Animals Rights (A.F.A.D.A.) grounding their reasoning on the fact that Sandra (a 29 years old orangutan born in captivity in Germany and then to Argentina 20 years ago) has "sufficient cognitive functions" in order not to be treated as an object. Those functions encompasses, for instance, the ability of keeping emotional ties, perceiving the passing of time, being able of learning, communicating and passing on information learned. The Court of Buenos Aires has therefore established that Sandra has to entitled with fundamental rights relating a "non-human individual" that is, a sentient individual even if it does not included in the human beings' category. This assumption opens the doors to the application and enactment of the right to put animals in captivity back on liberty (animals in zoos, circus, laboratories etc...). Broadly speaking, the court recognized the value of animals as autonomous subject of rights, worthy of judicial protection per se and not with regard to its owner's rights. This assumption leads to the philosophical notion of "persona" that is an individual with legal capacity, with speaking skills and ethic perception. The issue at stake is wide and complex. On this topic: http://www.corriere.it/animali/14 dicembre 22/sandra-orangopersona-non-umanaliberata-zoo-b566b8d2-89f5-11e4-a99b-e824d44ec40b.shtml?refresh ce-cp. This decision seems to have a sequel recently. The Court of Mendoza, in fact, in a decision held in November 3, 2016, established that a 30 years old chimpanzee called Cecilia had to be moved from a zoo in the city of Mendoza to a habitat suitable for her skills. The Court, indeed, stated that the chimpanzee was a "sujeto de derecho no humano". References on: http://scienze.-fanpage.it/la-scimpanze-cecilia-a-30-anni-e-libera-la-storicasentenza-rispettate-i-suoi-diritti/

In this respect, in 2013 India recognized dolphins to be non-human individuals and sentenced shoes in Acquariums to be illegal. In 2007, the Balearic Islands provided the first full-fledged legislation in the world about great apes' rights. According to it, great apes can no more be trapped or tortured even for scientific aims. However, yet in 2002, Germany, modifying its own Constitution, enshrined specific animals' rights. This way, Germany became the first European Union Member to ban scientific tests on animals for cosmetics industry and over-the-counter drugs. Moreover, rules of conduct for those keeping animals, both in public or private structures, in captivity had been set up. Likewise, Switzerland, a non-EU Member States, modified its own Constitution in this respect in 1992. In 1999, New Zeeland ensured for five species of great apes some fundamental rights like the ban on scientific tests on them. References on this topic at: http://www.wired.it/attualità/ambiente/2014/12/24/persone-non-uname-nel.mondo/. On this issues, the contribution by KEMELMAYER DE CARLUCCI A., La categoria juridical "sujeto/objeto" y su insuficiencia respect de los animals. Especial referencia a los animals usados en laboratorios, in Revista Anuario de la Facultad de Derechoh, Càceres, Universidad de Extremadura, Argentina, 27, (2009) 311.
} 
of a pet following a divorce or separation. The actual trends, as confirmed by jurisprudence and scholars from all over the world, reveals a preference for the latter interpretation ${ }^{7}$. It is sufficient to recall as evidence the "Universal Declaration of the Animals' Rights" concluded by the International League on the Animals' Rights on January 26 of 1978, signed by scholars, philosophers and scientists, and proclaimed in Paris at the UNESCO seat on October 15 of the same year. It is noteworthy to focus on the Preamble of the Convention stating that:

Each animal has its own rights; - Disowning and repudiation of those rights have led men to commit crimes against nature and animals; - the recognition by humankind of the right of other species to exist constitutes the bass for a peaceful coexistence of different species in the world;- genocides are pursued by men and many more are about to come; - As far as men respect other men, they will be able to respect animals too; - the respect and compassion for animals has to be promulgated through education from early stages.

As for articles contained in the Convention, some are particularly relevant.

- Article 1: All animals are born equal with respect to life and have the same right to existence.

- Article 2: a) Each animal has right to be respected; b) men, as animal species, is not entitled to exterminate or exploit other animals, violating this right. Men have right to put their knowledge in good service of animals; c) each animal has right to receive consideration, care and protection by men.

- Article 3: a) No animal should undergo ill-treatments and other cruel actions; b) if an animal suppression is deemed to be inevitable, it has to be instantaneous, without pain nor anger; (omissis).

- Article 10: No animal should be used for men's entertainment; shows using animals are incompatible with the animal's dignity.

- Article 11: Any act, not grounded on reasonable motivation, leading to the animal's death is deemed to be a "biocid", namely, a crime against life.

- Article 12: Any act leading to the massive killing of wild animals is genocide, namely, a crime against the species. Pollution and environment's destruction lead to genocide.

- Article 13: Once the animal is dead, it has to be treated respectfully; violent scenes whose animals are victims must be prohibited at cinema and on television, with the exception of those scenes aiming at showing an attack against animals' rights.

- Article 14: (omissis); Animals' rights must be protected as much as human rights.

In the author's opinion, the last provision clearly shows the attempt in considering animals as not only relating to human beings but also as per se living beings. Another important provision to be recalled is the "European Convention on the protection of pet animals", signed by Member States of the European Council in Strasbourg on November 13, 1987, enacted on May 1, 1992, ratified by the Italian Parliament with provision 201/2010.

The concerned Convention indicates in the Preamble that "men have the moral duty to respect all living beings (...) constraints between men and pets are specific (...) due to the relevance pet animals have in determining the quality level of life and therefore their value for the society, the importance of pet animals is noticeable"; furthermore, it is stated that "treating wild animals as pet ones should not be encouraged (...) pet animals are not always treated fairly, with due respect of their health and wellness (...) variations on people's behaviours towards pets are often caused by lack of knowledge and consciousness"; therefore (...) "providing general rules of conduct for a responsible behaviour by pet animals' owner is a desirable and realistic goal."

Subsequent provisions contained in the Convention fixed principles and definition to be analysed in their main features for the aim of this work.

In the first chapter, called "General provision", at art.1, the definition of "pet animal", described as "any animal which is detained, or about to be detained, by an individual, in particular in his/her private house, for his/her pleasure and company".

The second chapter, "Principles for the pet animals' maintenance", in the art. 3 establishes the "fundamental principles for animals' wellness" and states that "none will cause needlessly any sort of pain to pet animals (...), none must abandon his/her own pet animal". Moreover, Art. 4, called "Maintenance", provides that "every person detaining or taking care in any form of a pet animal is deemed to be responsible

${ }^{7}$ PITTALIS M., Separazione personale dei coniugi e “affido" dell'animale di adozione, in Famiglia e diritto, 12 (2016) 1165 ss 
for the health and wellness of the pet (...); "every person detaining or taking care of a pet animal must provide for adequate installation and cares for the pet, taking into account the ethological needs of the pet with regard to its species and race. In particular, the responsible of the pet has to: a) feed the pet adequately; b) providing adequate change for the pet to move; c) take adequate measures in order to avoid any pet's escape".

Going head, Art. 7, concerning "Training" asserts "no pet should be trained with methods that can put at risk the pet's health and wellness, forcing, for example, the pet to overcome its natural strength and abilities, or using artificial methods that can cause needlessly pain and wounds". As explained above, the European Convention has been ratified in Italy in 2010. Before that ratification, both at national and regional level, provisions, aiming at making the European provision effective, had been already enacted, sometimes overcoming the minimum standards set in the convention itself. Nevertheless, in those last provisions, administrative and criminal penalties in support of Art.10 and 12 on surgery operations on pets and duties of identification of pets were lacking.

It is only with the ratification occurred in 2010, that such administrative and criminal measures have been introduced or increased especially in the case of pets' killing and ill-treatment whose prohibitions have been already set in art 544 bis and ter of the Italian criminal code (thanks to the enactment of legislative provision n. 189 of 2004). However, the criminal code's provisions were addressed to the protection of humans' feelings towards animals rather than to animals straightforwardly as it is confirmed by the tile of the chapter containing the given provisions ("Provisions on animals' ill-treatment banning and on illegal animals' fighting or non-authorized competitions").

Moreover, the concerned 2001 law established that for cases figuring out as "illicit traffic of pet animals" as enshrined in art. 4 of the provision a criminal penalty is provided, while different cases are addressed to administrative measures.

In the end, another international provision is noteworthy: the 2007 "Lisbon Treaty" modifying the EU Treaties. In particular, art.13 of the Treaty on the Functioning of the European Union states that:

In formulating and implementing the Union's agriculture, fisheries, transport, internal market, research and technological development and space policies, the Union and the Member States shall, since animals are sentient beings, pay full regard to the welfare requirements of animals, while respecting the legislative or administrative provisions and customs of the Member States relating in particular to religious rites, cultural traditions and regional heritage.

Noteworthy is therefore the fact that animals are textually considered as "sentient living beings" whose wellness is to be pursued by necessity and not merely as movable property.

Coming back to Italian internal law, it has to be mentioned a provision within the reform on building apartments (namely, art. $161.220 / 2012$ ) adding a comma on art.1130 of the Italian civil code stating norms contained in the building apartment regulation cannot prohibit the detention of pet animals.

Finally, particularly relevant is the provision contained in art.1 of the Lombardia's regional law (1. 16/2006) concerning "Fight against the phenomenon of stray animals and protection of pet animals". The given article asserts the region "recognizes to pet animals the dignity of living beings and the respect for their physiological and ethological needs" condemning any kind of ill-treatment as abandons.

As for jurisprudence, both the relation between pet animals and men on the one hand and, on the other, the notion of pet animal per se have undergone a considerable evolution. In fact, at the beginning, the Supreme Court asserted that the Italian Constitution does not protect the relation between individuals and animals and, therefore, it does not lead to any right for compensation for damages caused by the loss of the pet animal due to third parties' actions. ${ }^{8}$ Courts then changed this position, claiming that the detention of a pet animal constitutes a full-fledged subjective right for people, enshrined in Art. 2 of the Italian Constitution. $^{9}$

In a decision concerning a case where a dog, because of its responsible negligence, has been carried on for a certain distance by its owners' car, being its leash stuck in the car door, the Criminal Section of the Court of Cassation stated that "the relationship between the owner and the pet animal is no more comparable

\footnotetext{
${ }^{8}$ Court of Cassation, decision n.14846/2007, "Danno e resp.", 1 (2008) 36, with notes by Foffa; again in "Resp. civ.", 8-9 (2008) 709 with notes by Villani; in "Nuova giur. Civ. Comm.", 2/1 (2008) 211, with notes by Cricenti. Recalled are as well decision n. 26972, 26973, 26974 and 26975/2008 of the Court of Cassation in "Resp. civ. Prev." (2009) 73 with notes by Monateri - Navarretta - Poletti - Ziviz; in Giur.it, (2009) 317, with notes by Tomarchio: in Dir. Fam. Pers. (2009) 73, with notes by Gazzoni; in Riv. Dir. Civ. With notes by Busnelli; in Rass. Dir. Civ. (2009) 499, with notes by Tescione; in Danno e resp. (2009) 73, with notes by Procida Mirabelli Di Lauro - Landini - Sganga - Gazzara. However, in favour of compensation, Court of Cremona (June 9, 2011) in Pluris.

${ }^{9}$ Court of Varese, December 7, 2011, in Pluris.

208 Derecho Animal. Forum of Animal Law Studies, vol. 10/1
} 
to the property of an object whose owner has fully at his/her own disposal" and that "the animal carried in a car under the custody of its responsible requires attention and diligence as much as a minor does". ${ }^{10}$ Still, the decision by the above-mentioned Court of Foggia ${ }^{11}$ indicates the necessity of "ensuring the best development possible of the pet animal's identity" and the identification of the animal as "sentient living being", leaving apart the traditional attribution of the animal in the res category 12 . To sum up, Courts have achieved important goals as: the protection of the "animal identity" of the pet; the existence and protection of "animals' rights" (hence, not only pet animals') pet anima 14 conceived of as "sentient living being" 15 and, in the end, the "material, spiritual and affective interest" of the animal (as stated in the case analysed in this work) ${ }^{16}$. All that demonstrates an increasing need in framing animals as autonomous subject of rights and not as mere object of the rights only attributable to individuals. ${ }^{17}$

\section{The material, spiritual and affective of the pet}

For the aim of this work, it is useful to compare two decisions: the one carried out by the Court of Rome and another one by the Court of Como. Despite the fact that they are quite contemporary (the latter was released just one month before the former), their contents considerably differ. In fact, the Court of Como, as already seen, agreed on the parties' consensual proposal concerning the assignation of a pet after the parties' separation ${ }^{18}$.

In deciding this way, the Court has confirmed the traditional conception of animals as belonging to res category. In its view, all aspects concerning the detainment of a pet are allocated in typical civil law institutes: in particular, costs for pet's maintenance consist in costs pertaining family affairs; then, the relation between the individual and the animal consist in a general obligation of civil law nature and, in the end, the responsibility of the owner toward the pet exists as non-patrimonial interest of the individual over the pet as stated in Art. 1174 of the Italian civil code. Moreover, the Court of Como deemed the identity in the vocabulary courts use when it comes to assert pet or children custody cases to be "improper". This Court, in fact, labelled this identity as a "fall from grace" culturally speaking. The concerned Court also stated that, in case of spouses' separation, Courts are required neither to decide on pet custody nor to define in judicial terms the relation existing between pets and individuals and it has defined just as "possible" and not "desirable" (as the Court of Rome did) the enactment of the law adding Art. 455 ter in the Italian civil code on "custody of pet in case of spouses' separation". In the mentioned legislative proposal, hearings of

\footnotetext{
${ }^{10}$ Court of Cassation, Criminal Section, decision n. 21805/2007, to look at in http://www.federfida.org/index.php/leggi-tutelaanimali/sentenze-cassazione/292-italia-cassazione-n-218052007-qcolpevole-di-reato-proprietario-che-disattenzione-trascina-canecon-automobileq.

11 In note 3

12 Court of Milan, March 13, 2013.

13 See the "Universal Declaration of animals' rights", partially quoted above.

${ }^{14}$ In this respect, the "European Convention on the protection of pet animals" and "the Lisbon Treaty", mentioned above, and the draft laws then mentioned.

15 In particular, the Lisbon Treaty and the decision by the Court of Milan on march 13, 2013.

${ }^{16}$ Besides the report on the Brambilla and Castiello draft law.

${ }^{17}$ In the respect of the "law giving evidence of the subjectiveness of the animal", LOMBARDI VALLAURI, L., "Testimonianze, tendenze, tensioni del diritto animale vigente", in Castiglione - Lombardi Vallauri; "La questione animale", in "Trattato di bioetica" (Milan 2012) 249 ss., in particular at pp. 255 and 259, where it is stated that the wording used by the whole normative system, both national and international, highlights that such a system "has no doubt on the subjectiveness of living beings whose exploitation and objectification has been dramatically allowed". In the worls mentioned, a legislative amendment introducing a constitutional protection over animals is desirable; RESCIGNO, F., "L'inserimento della dignità animale in costituzione: uno scenario di "fantadiritto?", within "La questione animale", op. cit, at 267 and 276 where the author first points out the Italian normative history as for animals' protection and then states as follow "the jurist has a duty to consider, besides the subjectiveness of human beings, that of animals as well" and that "the missed recognition of the subjectiveness of animals is no more justified on the ground of the absence of communication skills in animals or their inability in pursuing their own rights, because arguing this way would lead to the exclusion of subjectiveness of human categories like children or people with disabilities (..). Such an exclusion is totally paradoxical insofar as it is for weaker categories that rights are to be furtherly enhanced". Again, RESCIGNO, F., in "I diritti degli animali, da res a soggetti" (Torino 2005). In this respect, MAZZONI, C.M., "La questione dei diritti degli animali", in "La quesitone animale", op. cit., at 281 and following, where the author affirms that "all norms about protection of animals concerning protection against pain and early death of animals would demonstrate that a right of the animal per se exists". Moreover, at 290 , where several authors affirming an ad hoc legal personality of animals are mentioned, it is stated that, besides the legal personality recognized to individuals and associations, a legal personality of animals should be set up. The Author, however, argues that "the interest worthy of judicial protection can be addressed to living beings different from legal subjects" on the ground that duties of solidarity enshrined in Art. 2 of the Italian Constitution can be interpreted as extensively as to encompass men-animals relationships. Moreover, men have to deal with "specific rules of conduct, not considered to be proper rights" when relating with animals. On the same issues, VALASTRO, A., "La tutela giuridica degli animali e I suoi livelli", in Quaderni costituzionali (2006).

${ }^{18}$ Court of Como, February 3, 2016. References are at note 1.
} 
specialists in animals' behaviours are encouraged. The Court of Como described that provision as resulting from "the fantasy of the legislator" and, even if it ended up ageing on the parties' proposal, the Court suggested parties to address next disputes concerning pets' custody extra judicially. It means that, in case of spouses' separation, when there is no agreement on the custody of the pet, the judge is not entitled to ascertain anything in that respect. In another case (March 2, 2011), the Court of Milan agreed with the judge of Como.

The alternative orientation developed by the Court of Rome grounds on the idea that animals do not belong to res category. Therefore, norms about the custody of minors are applicable to pets' custody in case of both consensual and no-consensual spouses' separations as well.

In particular, the Court of Foggia, with a decision ${ }^{19}$ recalled by the Court of Rome itself, decided a case of judicial separation stating that the judge can decide to give the custody of the pet to one of the exspouses under the obligation of taking care of the animal while the other spouse can take care of the pet for certain hours a day each day; in the given case, the custody of the pet has been given to the party deemed to be more adequate for ensuring the best development possible to the pet identity. ${ }^{20}$

However, the decision does not represent the precedent in cases concerning the shared custody of a pet decided upon spouses' disagreement. In fact, this decision has established the custody of the pet just to one of the ex-spouses, leaving the other with visiting rights only.

In a subsequent case of consensual separation recalled in the decision which is at stake here, the Court of Cremona (June 11, 2008) ${ }^{21}$ established that both spouses could take care of the pet with equal division of costs for pet0s maintenance.

Still, on the same ground, noteworthy is the decision of the Court of Milan (March 13, 2013) ${ }^{22}$. This is recalled neither in the decision of the Court of Rome nor in that of the Court of Como. In this case concerning a consensual separation the Court went as far as to affirm principles even more protective of animals where it observed that "in the current order - due to the enactment of the law ratifying the European Convention on the Protection of pet animals - feelings for animals have constitutional and European relevance so that a full-fledged subjective right has to be addressed to pet animals" and that "an evolutionary interpretation of the current norms impose to understand that animals can no more conceptually be conceived of res...but they have to be recognized as "sentient living beings" (see the Treaty of Lisbon which institutes the European Union modifying its treaties). The right for the parties to regulate the permanence and the rules of conduct in order to take care of the pet is therefore legitimate". In the case decided by the Court of Milan, a couple with a child had some cats. Due to the couple's separation, the relating agreement established the custody of cats was attributed to the mother insofar as the child was under her custody. Moreover, she had to bear ordinary expenses while extraordinary ones were equally divided between both parents. Hence, the permanence and custody of pets were regulated by parties themselves and the judge agreed on their decision so that parties' interest was adequately balanced with the minor's one.

It is clear that the latter decision, that issued by the Court of Milan, is inspired by a way of thinking of animals not as res but as "sentient living beings" that is as creatures capable of "feeling emotions" an, particularly, of feeling physical and psychic pain, in line with European principles. ${ }^{23}$

This orientation has clearly inspired also the decision held by the Court of Rome which has in fact recalled both decisions of Foggia and Cremona but forgot to mention the even more revolutionary decision of Milan. As a matter of fact, in that case, precisely held for deciding the custody of a pet to one of the two ex-spouses after the cessation of a non-marital cohabitation, the Court stated that the above-mentioned decisions "applied by analogy norms about children custody" and, in deducing a principle from those decisions, affirmed that "the privileged interest of both decisions... has been exclusively the material spiritual - affective interest of the pet."

The Court of Rome is therefore the first court that came up with the principle of "material-spiritual and affective interest" of the animal, which is autonomous even if it has to be balanced with the affective interest of one of the two pending parties. The Court then fixed that principle as criterion for the analogical application of norms about children custody (all inspired by the realization of the material and moral interest of children) to pet custody.

Besides, it has to be noticed that the judgment did not generally identify the animal's interest in

\footnotetext{
${ }^{19}$ See again http://www.lalegge-pertutti.it/2778in-caso-di-separazione-a-chi-viene-affidato-lanimale-domestico.

${ }^{20}$ Likewise, the Court of Pescara, May 9, 2002.

${ }^{21}$ References about the decision on : http://www.quotidianogiuridico.it/documents/2016/03/30/separazione-consensuale-visita-emantenimento-del-cane-rientrano-nell-accordo.

22 See note 5 .

${ }^{23}$ Among all, CASTIGNONE, S., Psicologia della relazione affettiva tra l'uomo e gli animali, in "La questione animale", op. cit., 113.
} 
animals' "wellness" or, as stated by the Court of Foggia, "in the best development possible of the identity of the animal." Rather, it is represented as "the material-spiritual-affective interest of the animal" (recalled by he Court of Rome twice), a definition which is intentionally more nuanced than the "material and moral interest" definition used for children custody ${ }^{24}$. It was necessary, in fact, to highlight the features of the interest of an animal that differ from those pertaining individuals. That is why the same definition for both children and pets is not desirable.

At this point, it is useful to understand the meaning of the given definition. The significance of material and affective interest is certainly intuitive while less clear is the meaning of "spiritual" interest. If addressed to an animal, it can be interpreted as the interest of the animal itself in expressing its own nature and its temper, to sum up, its own identity ${ }^{25}$.

No relevance is to be given to "owner" indicated in the microchip of a pet (which relies on a notion of the pet considered as a "res"). Rather, the analogic correspondence between the moral and material interest of the children on the one hand and the material-spiritual and affective interest of the animal is to be enhanced with subsequent application of norms on children custody after parents' separation.

After all, as already stated, this is not the first time the jurisprudence expressly compares children and pets when it comes to protection. ${ }^{26}$ In this respect, the decision in comment has particular relevance insofar as it considers pet animals as autonomous subject of material, spiritual and affective interests, highlighting a transition from an objective to a subjective consideration of the pet itself.

The Court of Rome gave further evidence. It assessed positively the legislative proposal presented before the Italian Parliament ${ }^{27}$ when pet animals are better called "familiar animals". Again, when the Court encourages the enactment of Art.455 ter in the Italian civil code, establishing that the custody of the pet should be addressed to the part who can better provide to pet's "wellness". All those aspects mark a trend that is depicting pets as full-fledged family members. In fact, the Court of Rome precise that "owners" is an unfair label to indicate those who are responsible of pets. Besides that, the Court underlines that the pet interest is not only material but also spiritual and affective. It then focus on "the pet's point of view" and stated that the shared custody of the pet can be set also in case of cessation of non-marital cohabitation (and this decision occurred before the enactment of the law concerning the "Regulation of same sex civil unions" which contains a similar provision). This statement is even more enhanced currently due to the introduction of the law n.76/2006 ${ }^{28}$ and it is applicable to same sex unions, non-marital cohabitations ${ }^{29}$ and cohabitation without a stable registration (as stated by art.1.37 of the given provision) encompassing also situations in which the cohabitation is lacking at all. ${ }^{30}$

In the end and after all, the shared custody can be addressed by judges on the ground that "from the dog's point of view, which is the factor who ultimately counts" it is irrelevant whether their "owners" are married or not "as it happens with children which, contrary to pets, can perfectly understand whether their parents are married or not but do not perceive this aspect as relevant at all".

\section{The custody of the "family's" animal in case of relationship crisis: perspectives in the light of legal changes.}

In the absence of a provision establishing that, in case of any relationship crisis, the judge has duty to ascertain the custody of a pet, Courts can decide with discretion. It can sometimes opt out for the exclusive custody of the pet to one or another of the parties, or to both of them and sometimes reject questions in this respect with a declaration of inadmissibility.

It depends of course on the degree of sensibility a judge has and on whether the judge considers the pet as a subject of rights or not. In order to overcome this uncertainty for the legislative shortcoming and because of cases concerning custody of pets following relationships' crisis are increasing, three legislative proposals have been carried out. They are particularly relevant on the issue at stake and differ considerably

\footnotetext{
${ }^{24}$ See Art. 337 bis of the Italian civil code.

${ }^{25} \mathrm{See}$ in this respect, Court of Foggia above mentioned

${ }^{26}$ As stated above in note 10 . The Court of Cassation, criminal section, has itself stated that, for the animal's sake, "when carried on a car, the animal requires the same level of care and diligence normally attributed to children caregiving". Court of Cassation, decision n. 21805/2007.

${ }^{27}$ Draft law n. 3231 of the XVI Legislation proposing to introduce in the Italian civil code the "Chapter XIV bis. Of animals" containing various norms as art. 455 ter.

${ }^{28}$ Published in the Official Journal, n.118 in May 21, 2006.

${ }^{29}$ Art. 1.36 of the law 76/2016 states that "... "non-marital cohabitation means that two adults, in a stable relationship with moral and material duties, are not linked either by parental relationships or adoption or marriage or civil union".

${ }^{30}$ Likewise Arceri argues about the shared custody of children: ARCERI, A., Affidamento dei figli ed autonomia delle parti, in ARCERI, A., SESTA, M., L'affidamento dei figli nella crisi della famiglia (UTET Giuridica 2011) and La nuova giurisprudenza di diritto civile e commerciale (Bigiavi 2012) 89 ss, spec. 101
} 
from each other. At first, the proposal n. 3231 by the XVI Legislature contains the above-mentioned art. $455 \operatorname{ter}$ ("Custody of family's pets in case of spouses' separation") which states:

In case of spouses' separation and in the absence of any agreement between parts, the Court gives either the shared or the exclusive custody to the part who can provide the greatest level of wellness to the pet. The decision is taken regardless of any communal or separated estate settlement and regardless of any information provided by the registry office about the pet. Hearings with spouses, cohabitants, their progeny and, possibly, specialist in animals' behaviours are set before the final decision. The Court is competent for deciding upon the custody of a pet even in case of cessation of non-marital cohabitation

As already noticed, the provision calls pet animals as "family's animals". It likely aims at conceiving of pets as full-fledged family members. The proposal however still defines in terms of "property" the relation between individuals and pets.

Moreover, the proposal contains also provisions on the application of the shared or exclusive custody even in cases of cessation of any cohabitation and that the criterion over which the decision should be provided is that of the "best level of wellness ex-spouses can possibly provide to the pet. Again, the irrelevance of the information provided by the registry office about the pet is recalled and hearings of animals' behaviors specialists are provided too.

The "Animals Parliamentary Intergroup" has come up with the second legislative proposal, n.1392 during the same Legislature. Seven articles compose the draft law and their aim is to introduce remarkable modifications of the Italian civil code, procedural civil code and Italian criminal code and further modifications of other kinds. In particular, this second proposal deals with the issue about the custody of animals, defined even in this proposal as "family's animals", in a whole chapter where a series of principles are elaborated with regard to the issue at stake. The Chapter, called "Of Animals", is supposed to be added in the Italian civil code, after the title XIV. This "Of Animals" chapter, title XIV-bis, should provide as follows:

Art. 455 bis (Judicial protection of animals): Animals are sentient living beings. Provisions concerning individuals' civil rights are addressed to animals as well where compatibles and not in contrast with other specific provisions concerning animals. Animals are subject to special provisions about them and to provisions of the given code when applicable.

Art. 455-ter ("Custody of family's pets in case of spouses' separation") - In case of spouses' separation and in the absence of any agreement between parts, the Court gives either the shared or the exclusive custody to the part who can provide the greatest level of wellness to the pet. The decision is taken regardless of any communal or separated estate settlement and regardless of any information provided by the registry office about the pet. Hearings with spouses, cohabitants, their progeny and, possibly, specialist in animals' behaviours are set before the final decision. The Court is competent for deciding upon the custody of a pet even in case of cessation of non-marital cohabitation.

In the same Chapter there are also provisions on family's pets living in apartment buildings (Art. 455 quarter) and on pets after its owner passing (Art. 455 quinquies), on the prohibition of companion animals' foreclosure (Art. 455 sexies), on the access of pet animals to public areas and transport (Art. 455 septies), on the finding of abandoned, wounded animals and animals in danger (Art. 455 octies), on animals serving police (Art. 455 novies), on animals' selling (Art. 455 decies) and on the prohibition of ill treatments on animals (Art. 455 undecies). The latter provision establishes also that:

non-pecuniary and pecuniary damages caused to a pet animal can be addressed to its responsible. In case of exceptional highest order damage, non-pecuniary damages can be addressed to the pet itself for incurred serious injuries, together with damages addressed to the owner and to recognized animalist associations.

It is then useful to focus on Art.7 of the concerned legislative proposal concerning the definition of "Family's animal" as it states in the first comma:

Family's animal is said to be each pet animal detained by an individual with exclusion of food production. To detain in a family animals as cattle, pig, sheep, goat, horse, rabbit and poultry for 
company is allowed insofar as due communication is provided to the major and the National Veterinary Service in order to exclude any marketing, sale or slaughtering aim.

What emerges from this wording is that the animal is considered in the light of a "subjective" point of view. It is in fact defined as "living sentient being" and worthy of "provisions concerning human civil rights" where "compatible and not in contrast with other specific provisions about animals"; in line with this provision, the document does no more indicate those detaining pets as "owners".

Comparing the first and the second proposals, the latter indicates the possibility for the judge to set hearing with specialist "only when necessary" instead of leaving this option open to the discretion of the judge, as the former provides. Again, the latter indicates that custody is addressed "to the part who can provide the best accommodation for the protection for the pet" as main criterion and declares "ordinary court" as the judicial organ competent for deciding in the respect of pets' custody. The two proposals are similar for the rest.

Hence, the legislative proposal n. 1392 is just apparently more protective than the proposal n. 3231 in respect of pet custody following a relationship crisis. In fact, substantially speaking, it does not encompass any provision on the pet "wellness"; rather, it evokes only notion as "better accommodation" in relation with the "protection" of the pet, even if considered as a "sentient living being"; moreover, the specialist hearing is limited to necessary cases only while proposal n. 3231 leaves this option open to discretion of the judge. In the end, it elects as competent the ordinary court making a firm decision in this respect.

Nevertheless, in this proposal the pet is named as "family's animal". This is particularly relevant if we consider that a forthcoming legislative reform will revise how the competence of courts on children and family issue; precisely, a specific section is thought to be established in each ordinary court and relating court of appeal for those kind of issues while juvenile courts will be suppressed ${ }^{31}$. Those brand new sections, precisely aimed at settling children and family issue, could be, in the author's opinion, suitable for deciding upon pet custody insofar as those issues have familiar and personal implications as well regardless of any consideration about the resemblances between pet and children custody.

The third legislative proposal is more recent and, under several aspect, more different from the former two we analyzed. The draft, n.795 of the XVII Legislature, presented by deputies Brambilla and Castiello in april 18, 2013, provides the introduction of Art.155 septies in the Italian civil code about "pet custody in case of spouse' separation". The concerned article states in the first comma as follows:

In case of separation of spouses detaining a pet, the court, in the absence of parties' agreement, regardless of the existence or not of a communal estate settlement and regardless of what is stated in the documents about the registration of the pet, sets hearings with the spouses, their progeny and possibly with animals' behavior specialists and gives the shared or separated custody of the pet to the part who can provide the greatest level of wellness for the pet.

The second comma then establishes that:

In case of shared custody, with exclusion of any other concluded agreement, each party has meanstested duties with regard to the maintenance of the pet. In case of exclusive custody to only one of the parties, duties are against the one who has custody of the pet.

Therefore, the legislative proposal uses old-fashioned vocabulary as "owners", "pet animals" or "animals for company". It never mentions either the possibility of settle hearings of "cohabitants" or the cessation of non-marital cohabitation. It addresses to the discretion of the judge the option of hearing specialists and claim as "desirable" the fulfilment of the pet wellness. In the end, and differently from other proposals, it analyses the custody under the light of financial commitment: when the custody is shared, each responsible has to participle to costs proportionally to their incomes. Otherwise, if the custody is given to one of the parties, this latter only has to deal with costs.

It has to be noticed that this proposal is more consistent with norms and principles regulating children custody (namely Art. 316 bis and 337 of the Italian civil code) than with decision held by the Court of Como $^{32}$. The Court there imposed $80 \%$ of costs to be provided by one spouse and the lasting $20 \%$ by the other and established that the husband had a duty to put $€ 250$ a month to his wife as contribution for $\operatorname{dog}$ sitting and food costs. On the contrary, the Court of Rome has provided an equal division of costs. It is not

\footnotetext{
${ }^{31}$ See the draft law n. 2953 of the Chamber of the Chamber of Deputies in the XVII Legislation, available at http://www.camera.it/leg17/126?pdl=2953

${ }^{32}$ Court of Como, decision February 3, 2016.
} 
clear whether this decision has depended on the fact that parties had the same economic capacity or not.

Coming back to the legislative proposal n. 795, noteworthy is its Presentation Report. There it is reported in fact that in Italy, a half of families almost lives with a pet; therefore, cases in which pets, more and more deemed to be family members, are cause of disagreement in cases of separations.

In this respect, the Treaty on the Functioning of the European Union is mentioned too where it defines animals as "sentient living beings"; the above-quoted decision held by the Court of Cassation in $2007^{33}$ is recalled about the comparability of children and pets when it comes to assert the amount of diligence to be provided for their protection. Furthermore, the Report recalls all judicial decisions about pet custody after separations where norms on children custody have been applied by analogy with due regard of the "material spiritual and affective interest of a pet animal disputed by a couple". ${ }^{34}$

Hence, the author encourages the enactment of a provision resulting from the balance of all draft norms and consequent critics. The content of this provision can be:

As for family's animals, in case of spouses' separation, the court, in the absence of an agreement between parts, gives exclusive custody to one of the two or to both of them, according to the realization of the material-spiritual and affective interest of the pet and regardless of any communal estate settlement and information provided by the registry office. Hearings of spouses, cohabitants and their progeny and possibly with specialists must precede the decision. The Court is competent in deciding the custody of the pet even in case of cessation of non-marital cohabitation.

In case of shared custody, with exclusion of agreement freely concluded by parts, each one of the pet responsible has means-tested duties for the pet maintenance. In case of exclusive custody to of the two parts, only the latter is responsible for the maintenance of the pet.

This wording is innovative with regard to the previous draft law for two reasons: it indicates as criterion for settling the custody of a pet its own material spiritual and affective interest and settles the hearings with a specialist as a necessary condition for deciding the case and not as a mere option for the judge. As in children custody case the minor can be heard (see Art. 377 octies of the Italian civil code), the hearings from animals' behaviours specialist are deemed to be adequate substitute for pet custody.

Other aspects consisting in the corollary of the applicability to pet custody of the norms on children custody derived from Art. 377 septies and subsequent articles of the Italian civil code. Those aspects have not been the object of any legislative provision so far.

Therefore, courts can decide discretionally upon the pet custody ${ }^{35}$ and can agree with conditions set by parts if conditions are respectful of the material-spiritual and affective interest of the pet that is the ultimate goal to fulfil. Otherwise, the judge him/herself can revise conditions. ${ }^{36}$ The same happens with children custody as stated in Art. 377.2 ter of the Italian civil code.

In particular, in case of consensual separation, the judge can analyse specifically the content of a given agreement and, when in contrast with the interest of the animal, the judge can decide not to apply it. On the contrary, the Court of Como ${ }^{37}$ stated that the judge is competent only for verifying whether the agreement at stake is contrary to public policy.

The judge is competent for reviewing the content of the agreement as provided in case of children custody. Like Art. 377.3 ter and Art. 3 quater, whether the custody is shared or exclusive, main decision concerning the pet (basically healthcare issues) are to be taken by both parties with due regard of the pet wellness $^{38}$; on the contrary, as for ordinary issues, the judge can establish that parties can decide separately even when the custody is shared.

In this respect, the decision of the Court of Rome is particularly relevant insofar as it stated that "both ex-cohabitants have to take care of the pet" providing therefore a conjunctive duty of caregiving which implicitly reminds of the caregiving parents have to provide to children in the words of art. 377 ter of the Italian civil code. In case of non-compliance of the placed custody conditions, the judge can modify them also on the ground of the behaviour of the non-compliant part. (art. 377.3 ter).

Likewise art. 337 quater of the Italian civil code, the judge can decide for the exclusive custody only

\footnotetext{
${ }^{33}$ Court of Cassation, Criminal Section, decision n. 21805/2007.

${ }^{34}$ The Report itself recalls several times the decision of the Court of Foggia and the principles the Court established in there.

35 See on children issue, among all, ARCERI, A., Affidamento dei figli ed autonomia delle parti, in ARCERI, A., SESTA, M., L'affidamento dei figli nella crisi della famiglia (UTET Giuridica 2011) and ARCERI, A., in La nuova giurisprudenza di diritto civile e commerciale (Bigiavi 2012) 89, spec. 114

${ }^{36}$ On the atypical nature of Art. 1322 of the Italian civil code, regulating agreements aimed at defining inheritance after a separation, see again ARCERI, A., Affidamento dei figli, op. cit., 111.

${ }^{37}$ Court of Como, February 3, 2016.

${ }^{38}$ In this respect, GAVINELLI, A., Il benessere dell'animale: una scelta europea, in La questione animale, op. cit. at 817

214 Derecho Animal. Forum of Animal Law Studies, vol. 10/1
} 
to one of the parties through a motivated court order on the ground that to give the custody to the other part will go against the interest of the pet itself. Likely, in the same case, each part can ask for the exclusive custody anytime, regardless of the fact that initially the court had decided for the shared one. It means that, even if the decision set a shared custody, each part must watch over the effective realization of the interest of the pet in any time and is entitled to go before the court when the counterpart does not comply with these duties or take detrimental decisions for the pet itself.

Moreover, the author claims as inappropriate the comparison between the custody of a pet and that of children to be inappropriate. The Court of Foggia, conversely, compared the two situations several times in order to justify the exclusive pet custody to the part having in custody the children and the Court of Milan did the same in 2013 when, after having applied a consensual separation, the custody of some cats has been given to the mother having in custody her children.

In this respect, it seems wrongful to balance the interest of a child who wants to have the company of a pet and the interest of the pet itself. Instead, it is necessary to evaluate those interests autonomously and, if possibly, satisfy the interest of the child through and only after the decision on the rules of conduct of exspouses as for the custody of the pet.

Still, another norm on children custody applied by analogy on the issue at stake is Art. 337 quinquies of the Italian civil code. It regulates the faculty for parties to ask for the review of the decision on the pet custody and on rules and modes for maintaining the pet in any time.

As for Art. 377 sexies of the same code, the author considers that the custody and allocation of the pet have not to interfere with the decision on the attribution to one or another part of the family house where the interest of the child is the main principle at stake.

In fact, the pet interest is not more important that the interest of the owner in his/her family house even when that house's characteristics are deemed to be more suitable for the detainment of the concerned pet (for instance, because it has a garden) than the house of the other part having the pet in custody.

Moreover, the provision of Art. 337 octies of the Italian civil code, concerning the power of the judge, it is necessary, as suggested before, to provide hearings of animals' behavior specialist instead of the hearing of the children in issue concerning children custody. Those hearings, by analogy with the hearing of the child, are not to be set when they appear to be in contrast with the pet interest under proper motivation; on the contrary, they can have a pivotal role when agreements between parts about the custody are at stake.

Finally, the judge competent for issues on pet custody is another relevant issue and, in the author's opinion, the judge competent for family issues should be competent for the pet custody too, taking into account that those issues have undoubtedly aspects that involve people as well as the case here demonstrates. 